\title{
Analisis Kapabilitas Aparat Pengawasan Intern Pemerintah (APIP) Daerah Kabupaten Kepulauan Talaud
}

\author{
NOVIA CYNTHIA MARADESA ${ }^{1}$, HERMAN KARAMOY ${ }^{2}$ LINTJE KALANGI $^{3}$
}

Program Studi Magister Akuntansi, Fakultas Ekonomi dan Bisnis Universitas Sam Ratulangi Email: noviamaradesa75@gmail.com ${ }^{1}$, hkaramoy@yahoo.com² ${ }^{2}$ lintje_kalangi@yahoo.com ${ }^{3}$

\begin{abstract}
This study aims to determine the state of APIP in the Regional Government of Talaud Regency and the APIP's constraints in carrying out its duties and functions as supervisors of Regional Government activities, and analyze the efforts that should be carried out to improve the capabilities of APIP, then provide some advices so that APIP can carry out their tasks and functions optimally. This is a qualitative research method with an exploratory approach. Data were obtained by in-depth interviews, documentation studies and observations. The results showed that the capability of APIP in the Regional Government of Talaud Regency was still at level II with a note. The constraints are amount of human resources, in this case the auditor has not been adequate with the existing workload and the lack of infrastructure that cannot supports the tasks and implementation of APIP. The efforts that can be made to improve the capabilities of APIP in the Regional Government of Talaud Regency are for human resource constraints can be done by increasing the number of auditors in accordance with the workload and including the auditors in technical training and training, seminars to improve the capabilities of the APIP conducted by BPKP and BPK as well as holding their own office training. Solutions to solve infrastructure problems are to add some infrastructures that supports the implementation of APIP tasks such motorcycles and vehicles, laptops, scan tables, hammer tests, and printers.
\end{abstract}

Keywords: APIP, APIP Capabilities, Constraints and Efforts.

Abstrak. Penelitian ini bertujuan untuk mengetahui keadaan APIP pada Pemerintah Daerah Kabupaten Talaud dan kendala apa saja yang di hadapi APIP dalam pelaksanaan tugas dan fungsinya sebagai pengawas kegiatan Pemerintah Daerah, serta menganalisa upaya-upaya apa yang harus dilaksanakan untuk meningkatkan kapabilitas APIP, kemudian memberikan saran terhadap upaya-upaya yang dapat dilakukan agar APIP dalam menjalankan tugas dan fungsinya dapat terlaksana dengan optimal. Metode penelitian yang digunakan adalah metode penelitian kualitatif dengan pendekatan eksploratori. Data yang diperoleh peneliti melalui wawancara mendalam, studi dokumentasi dan observasi. Hasil penelitian menunjukkan bahwa kapabilitas APIP pada Pemerintah Daerah Kabupaten Talaud masih berada pada level II dengan catatan. Kendala yang dihadapi adalah jumlah sumber daya manusia dalam hal ini auditor belum memadai dengan beban kerja yang ada dan kurangnya sarana prasarana yang yang mendukung tugas dan pelaksanaan APIP. Upayaupaya yang dapat dilakukan untuk meningkatkan kapabilitas APIP pada Pemerintah Daerah Kabupaten Talaud adalah untuk kendala sumber daya manusia dapat dilakukan dengan menambah jumlah auditor sesuai dengan beban kerja dan mengikutsertakan auditor pada diklat-diklat teknis, seminar-seminar peningkatan kapabilitas APIP yang dilaksanakan oleh BPKP dan BPK serta menagadakan pelatihan kantor sendiri. Untuk kendala sarana prasarana, upaya-upaya yang dapat dilakukan adalah dengan melakukan penambahan sarana prasarana yang mendukung pelaksanaan tugas APIP seperti kendaraan roda dua dan roda empat, laptop, scan table, hammer test, dan printer.

Kata Kunci: APIP, Kapabilitas APIP, Kendala dan Upaya. 
Pendahuluan

Setiap negara memiliki cita-cita dan tujuannya masing-masing, di negara Republik Indonesia cita-cita dan tujuan nasional bangsa kita tertuang dalam Pembukaan UndangUndang Dasar 1945, yang berbunyi "kemudian dari pada itu untuk membentuk suatu pemerintah negara Indonesia yang melindungi segenap bangsa Indonesia dan seluruh tumpah darah Indonesia, memajukan kesejahteraan umum, mencerdaskan kehidupan bangsa, serta ikut memelihara ketertiban dunia yang berdasarkan kemerdekaan perdamaian abadi dan keadilan sosial" dan tertuang juga dalam Pancasila yaitu pada sila kedua yaitu "kemanusiaan yang adil dan beradab", dan pada sila kelima "keadilan sosial bagi seluruh rakyat Indonesia".

Dalam upaya mewujudkan cita-cita bangsa pemerintah mengeluarkan Peraturan Pemerintah (PP) Nomor 60 Tahun 2008 tentang Sistem Pengendalian Intern Pemerintah (SPIP). Peraturan ini ditetapkan untuk mengatur atau mengendalikan kegiatan pemerintah mulai dari tingkat daerah sampai pusat. The Institute of Internal Auditor (IIA) merupakan organisasi resmi yang memangku kepentingan profesi auditor internal mengeluarkan International Professional Practices Framework (IPPF). Jelasnya IPPF merupakan asas atau pedoman praktik profesional audit internal dalam melaksanakan fungsinya. Pada pasal 2 PP Nomor 60 Tahun 2008 tentang Sistem Pengendalian Intern Pemerintah mewajibkan pimpinan lembaga/menteri, gubernur, dan bupati/walikota melakukan pengawalan atas pelaksanaan kegiatan pemerintah untuk mencapai pengelolaan keuangan negara yang transparan, efektif, efisien, dan akuntabel. Lebih dari itu juga, pimpinan lembaga dan kementerian serta kepala-kepala daerah harus bertanggung jawab atas pelaksanaan SPIP tentunya dengan melakukan pengawasan intern atas penyelenggaraan kegiatan, tugas dan fungsi instansi pemerintah. Peraturan itu merujuk pada pelaksanaan tugas audit intern yang dimandatkan kepada Aparat Pengawasan Intern Pemerintah (APIP).

Aparat Pengawasan Intern Pemerintah (APIP) adalah instansi pemerintah yang dibentuk dengan tugas melaksanakan pengawasan intern (audit intern) di lingkungan pemerintah pusat dan/atau pemerintah daerah, yang terdiri dari badan pengawasan keuangan dan pembangunan (BPKP), inspektorat jenderal kementerian, inspektorat/unit pengawasan intern pada kementerian negara, inspektorat utama/inspektorat lembaga pemerintah non kementerian, inspektorat/unit pengawasan intern pada kesekretariatan lembaga tinggi negara dan lembaga negara, inspektorat provinsi/kabupaten/kota, dan unit pengawasan intern pada badan hukum pemerintah lainnya sesuai dengan peraturan perundang-undangan.

Pada saat ini APIP dalam pelaksanaan tugas dan fungsinya dituntut untuk meningkatkan kapabilitasnya pada level yang lebih terpercaya yaitu level III (integrated). Seperti yang telah diinstruksikan oleh presiden pada rakornas peningkatan kapabilitas dimana peningkatan kapabilitas APIP merupakan salah satu rencana pembangunan jangka menengah nasional 2014 - 2019 (RPJMN). Pentingnya peningkatan kapabilitas APIP itu sendiri didasari dengan cita-cita pemerintah untuk menciptakan tata kelola pemerintahan yang baik, bersih, akuntabel, dan berintegritas. APIP diharapkan mampu melaksanakan tugas sesuai dengan peraturan serta standar yang ada, dimana untuk menuju level III ada beberapa indikator yang harus dipenuhi serta dilakukan oleh API. Semakin meningkatnya level kapabilitas APIP makan semakin baik pula tata kelola pemerintahan sehingga cita-cita negara bisa tercapai.

Data BPKP terkait laporan capaian nasional kapabilitas APIP pada 16 Juli Tahun 2018 menyatakan bahwa Jumlah APIP Kementerian/Lembaga sebanyak 86 dengan capaian level sebagai berikut, 22 berada pada level satu, 24 berada pada level satu plus, 15 berada pada level dua, 20 berada pada level tiga DC, dan 4 berada pada level tiga, serta 1 belum initial SA. Sedangkan untuk APIP Daerah, jumlah APIP sebanyak 542 dengan capaian level sebagai berikut, 107 pada level satu, 97 pada level satu plus, 235 pada level dua, 103 pada level tiga DC. Total Capaian Nasional dengan jumlah APIP keseluruhan yaitu 628, capaian sebanyak 129 (20,5\%) berada pada level satu, 121 $(19,3 \%)$ berada pada level satu plus, $250(39,8 \%)$ berada pada level dua, $123(19,6 \%)$ berada pada level tiga DC, serta $4(0,6 \%)$ berada pada level 3, dan terakhir $1(0,2 \%)$ belum initial SA. Hasil capaian kapabilitas APIP sampai saat ini belum efektif dan berbanding terbalik dengan Instruksi Presiden tahun 2015 menerbitkan bahwa Kapabilitas APIP menjadi salah satu fokus dalam Rencana Pembangunan Jangka Menengah Nasional (RPJMN) 2015-2019 dengan target capai level III 85\% pada Tahun 2019. 
Laporan Hasil Pemeriksaan BPK Republik Indonesia Perwakilan Sulawesi Utara atas LKPD Kabupaten Kepulauan Talaud sejak 2006 sampai dengan 2013 mendapatkan Opini Tidak Wajar (TW) dan Disclaimer. Dan ditahun 2014 sampai tahun 2015 terjadi sedikit peningkatan opini yaitu menjadi Wajar Dengan Pengecualian (WDP). Hal itu disebabkan oleh permasalahan berulang diantaranya mengenai pengelolaan belanja modal, pengelolaan belanja barang dan jasa, pengelolaan belanja bantuan, dan hibah (Matei, 2017). Dan pada tahun 2016 dan 2017 Kabupaten Kepulauan Talaud telah berhasil memboyong opini Wajar Tanpa Pengecualian, akan tetapi opini yang telah diperoleh tidak mampu mendorong peningkatan level kapabilitas APIP daerah Kabupaten Kepulauan Talaud karena opini WTP yang telah diperoleh tersebut merupakan wujud dari kinerja APIP itu sendiri.

Dalam wawancara survei pendahuluan sejak dilakukan penilaian oleh BPKP pada tahun 2014 dengan hasil masih pada level I hingga tahun 2019 APIP Talaud masih berada pada level II. APIP Kabupaten Kepulauan Talaud terus melakukan pembenahan-pembenahan serta program kerja yang tepat guna sesuai dengan tugas fungsi yang sudah diatur dalam peraturan yang ada serta mengoptimalkan anggaran yang ada dalam rangka terciptanya APIP yang efektif dan bisa di percaya. Peraturan Presiden Nomor 2 Tahun 2015 tentang Rencana Pembangunan Jangka Menengah Nasional Tahun 2015 - 2019, dimana peningkatan kapabilitas APIP pada level III merupakan salah satu indikator dalam RPJMN tersebut sehingga pemerintah daerah kabupaten Kepulauan Talaud sendiri telah mencanangkan juga pada RPJMD. Survei pendahuluan juga menyebutkan bahwa pada tahun 2018 Inspektorat Kabupaten Kepulauan Talaud mengikuti Quality Assurance Peningkatan Kapabilitas APIP menuju Level III oleh BPKP pada tahun 2018, dengan hasil yang dicapai yakni APIP Kabupaten Kepulauan Talaud masih berada pada Level II dengan catatan. Berdasarkan hasil penilaian masih ada beberapa catatan yang perlu dilengkapi dan dibenahi lagi diantaranya penyusunan Program Kerja Pengawasan Tahunan (PKPT) belum berbasis risiko, pelaksanaan audit kinerja yang belum optimal, serta jumlah auditor yang kurang proporsional

Dari latar belakang serta survei pendahuluan yang sudah dijelaskan pada paragraf sebelumnya maka peneliti sebagai warga daerah Kabupaten Kepulauan Talaud termotivasi untuk memberikan sumbangsih kepada pemda dalam rangka terciptanya tata kelola pemerintahan yang baik dan bersih melalui karya ilmiah mengenai peningkatan level kapabilitas dimana hal ini merupakan salah satu indikator yang ada di RPJMN kemudian dituangkan juga dalam RMPJMD Kabupaten Kepulauan Talaud.

Tujuan dari dilakukannya penelitian ini yaitu untuk mengetahui keadaan APIP saat ini dan kendala apa saja yang di hadapi APIP dalam pelaksanaan tugas dan fungsinya sebagai pengawas kegiatan pemerintah daerah, serta menganalisa upaya dan strategi apa yang harus dilaksanakan untuk meningkatkan kapabilitas APIP pada Pemerintah Daerah Kabupaten Kepulauan Talaud. Kemudian memberikan saran serta masukan melalui penelitian ini terhadap upaya-upaya yang sudah dilaksanakan agar dalam pelaksanaan tugas dan fungsinya bisa teroptimalkan sehingga menghasilkan APIP yang integrated atau level III.

\section{Penelitian Terdahulu}

Penelitian yang dilakukan oleh Indah Supragita (2017) dari Universitas Gadjah Mada dengan judul penelitian "Evaluasi Efektivitas Aparat Pengawasan Intern Pemerintah (APIP) Kabupaten Bengkulu Utara". Dengan hasil dari penelitian menunjukkan bahwa lingkungan belum mendukung kedudukan APIP, kompetensi pelaksanaan audit belum memadai, dan proses audit belum efektif. Yang berarti bahwa, APIP Kabupaten Bengkulu Utara belum efektif.

Penelitian yang dilakukan oleh Marliani (2018) dari Universitas Syiah Kuala Banda Aceh dengan judul penelitian "Evaluasi Efektivitas Penguatan Peran Aparat Pengawasan Intern Pemerintah dalam Paradigma Baru". Hasil dari penelitian ini menunjukkan bahwa penggunaan metode, pendekatan, dan fokus audit di Inspektorat, belum secara keseluruhan memenuhi tuntutan paradigma baru peran audit intern yang berfungsi sebagai penjamin mutu (assurance) dan konsultasi (consulting).

Penelitian yang dilakukan oleh Rindu Rika Gamayuni (2016) dari Universitas Lampung dengan judul penelitian "Efektivitas Fungsi Audit Internal: Factor yang Mempengaruhi Dan Implikasinya terhadap Kualitas Pelaporan Keuangan (Survey pada Inspektorat Pemerintah Provinsi/Kota/Kabupaten di Pulau Jawa". Hasil dari penelitian ini menunjukkan bahwa (1) kompetensi auditor internal berpengaruh signifikan terhadap efektivitas fungsi audit internal; (2) 
objektivitas auditor internal tidak berpengaruh signifikan terhadap efektivitas fungsi audit internal; (3) dukungan manajemen berpengaruh signifikan terhadap efektivitas fungsi audit internal; (4) efektivitas fungsi audit internal berpengaruh signifikan terhadap kualitas laporan keuangan.

Penelitian yang dilakukan oleh Angela Mulyani Matei (2017) dari Universitas Sam Ratulangi dengan judul penelitian 'Optimalisasi Fungsi Inspektorat Dalam Pengawasan Keuangan Daerah Kabupaten Kepulauan Talaud". Hasil penelitian ini menunjukkan fungsi inspektorat dalam pengawasan keuangan daerah di Kabupaten Kepulauan Talaud belum optimal sehingga dibutuhkan strategi untuk mengatasi kendala-kendala dalam pelaksanaan fungsi pengawasan yakni (1) penambahan tenaga pengawas; (2) meningkatkan kompetensi APIP; (3) meningkatkan alokasi anggaran pengawasan; (4) penambahan fasilitas pengawasan; (5) mengoptimalkan peran APIP sebagai konsultan dan katalis; (6) pemberian sanksi tegas bagi SKPD yang lalai atau kurang berkomitmen terhadap pelaksanaan pengawasan; (7) adanya komitmen pemerintah daerah dalam bidang pengawasan.

\section{Model Analisis}

Model analisis pada penelitian ini menggunakan content analysis (analisis isi) yaitu membuat transkrip hasil wawancara, mendengarkan dengan saksama, kemudian menuliskan kata-kata yang didengar sesuai dengan apa yang ada di rekaman tersebut. Model analisis penelitian dapat digambarkan dalam kerangka konseptual penelitian seperti pada gambar 1.1 berikut ini:

Gambar 1.1 Kerangka Konseptual Penelitian

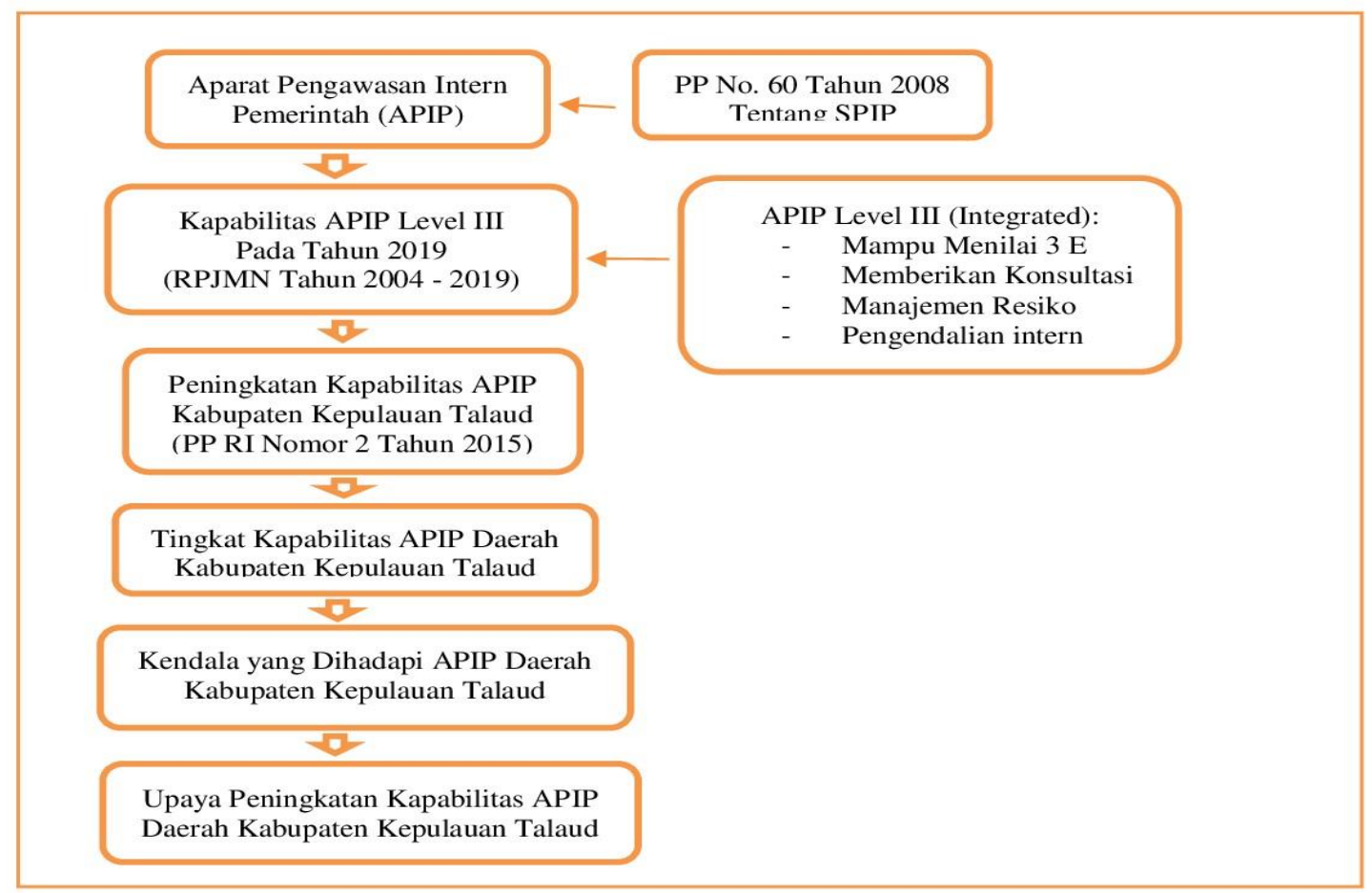

Sumber Data: Data Olahan (2019)

\section{Metode Penelitian}

Penelitian ini menggunakan metode penelitian kualitatif dengan pendekatan eksploratori (exploratory approach). Dengan metode ini peneliti ingin menggali informasi secara mendalam, serta hendak menggambarkan keadaan yang sebenarnya tentang kapabilitas APIP, kendala yang dihadapi, serta upaya yang dilakukan dalam meningkatkan kapabilitas APIP daerah Kabupaten Kepulauan Talaud agar terlaksana. Kemudian menganalisa kendala apa saja yang dihadapi APIP dalam pelaksanaan perannya sebagai pengawas intern pemerintah (Sugiyono, 2016).

Teknik pengumpulan data yang digunakan penulis dalam penelitian ini yaitu wawancara mendalam (in-depth interview), observasi dan dokumentasi. Informan dalam penelitian ini terdiri dari 
Inspektur, Para Inspektur Pembantu (IRBAN), Sekretaris, Kasubag, Auditor, Pegawai Inspektorat sebanyak 12informan.Uji kredibilitas yang dilakukan dalam penelitian ini menggunakan triangulasi sumber.

\section{Analisis dan Pembahasan}

Untuk menjawab permasalahan pertama ditemukan 1 (satu) tema yaitu: sumber daya manusia. Selanjutnya, untuk menjawab masalah kedua ditemukan 2 (dua) tema yaitu: kendala sumber daya manusia, kendala sarana prasarana. Dan untuk menjawab masalah ketiga ditemukan 2 (dua) tema yaitu: upaya mengatasi sumber daya manusia, upaya mengatasi sarana prasarana.

\section{Kapabilitas APIP Daerah Kabupaten Kepulauan Talaud Sumber Daya Manusia}

Berdasarkan hasil wawancara yang sudah diuraikan sebelumnya diketahui bahwa APIP Talaud untuk tingkat kapabilitas masih berada pada level II dengan catatan, ini disebabkan masih ada beberapa indikator level III kapabilitas APIP yang belum terlaksana seperti penyusunan PKPT belum berbasis risiko dan audit kinerja belum optimal serta kurangnya sumber daya auditor.

Selanjutnya berdasarkan hasil wawancara juga ditemukan bahwa APIP juga harus memiliki latar belakang pendidikan yang memadai dan sesuai dengan kebutuhan auditor selain itu pengalaman auditor dalam melaksanakan tugas sangat berpengaruh terhadap kinerja serta melalui pendidikan, diklat-diklat teknis auditor. APIP merupakan salah satu organisasi pemerintah khususnya daerah dalam melakukan pengawasan terhadap tata kelola pemerintahan sehingga kualitas sumber daya manusia sangat berpengaruh terhadap keberhasilan tujuan organisasi. Standar audit aparat pengawasan intern pemerintah Per/05/M.Pan/03/2008 pada standar 2200 mengenai keahlian, dimana auditor harus mempunyai pengetahuan, keterampilan, dan kompetensi lainnya yang diperlukan untuk melaksanakan tanggung jawabnya. Pimpinan APIP harus yakin bahwa latar belakang pendidikan dan kompetensi teknis auditor memadai untuk pekerjaan audit yang akan dilaksanakan. Oleh karena itu, pimpinan APIP wajib menciptakan kriteria yang memadai tentang pendidikan dan pengalaman dalam mengisi posisi auditor di lingkungan APIP.

Pada standar 2210 - latar belakang pendidikan auditor APIP harus mempunyai tingkat pendidikan formal minimal strata satu (S1) atau yang setara. Agar tercipta kinerja audit yang baik maka APIP harus mempunyai kriteria tertentu dari auditor yang diperlukan untuk merencanakan audit, mengidentifikasi kebutuhan profesional auditor dan untuk mengembangkan teknik dan metodologi audit agar sesuai dengan situasi dan kondisi yang dihadapi unit yang dilayani oleh APIP. Untuk itu APIP juga harus mengidentifikasi keahlian yang belum tersedia dan mengusulkannya sebagai bagian dari proses rekrutmen. Dari hasil wawancara pada informan diketahui juga sistem perekrutan auditor yang dilakukan oleh pemerintah melalui inspektur melalui test yang dilakukan oleh BPKP dan inpassing atau penyesuaian auditor dimana calon auditor mengikuti diklat dan memenuhi angka kredit kemudian dilakukan test untuk mendapatkan sertifikat auditor oleh BPKP.

Untuk kebutuhan auditor saat ini tidak selalu berlatar belakang sarjana ekonomi dan akuntansi saja tetapi sudah disesuaikan dengan kebutuhan pemeriksaan dilapangan, karena objek pemeriksaan tidak selalu pada aspek keuangan namun keseluruhan kegiatan pemerintah. Hal ini mempengaruhi kebutuhan latar belakang disiplin ilmu yang harus dimiliki oleh seorang auditor internal yang tidak lagi harus berlatar belakang akuntansi, namun APIP juga harus memiliki pemahaman yang memadai atas ilmu manajemen, ilmu-ilmu sosial, ilmu kesehatan, hukum maupun ilmu-ilmu teknik. Berbekal ilmu-ilmu yang komprehensif tersebut diharapkan APIP mampu berada selangkah di depan dan dapat mengantisipasi adanya indikasi kecurangan yang mungkin terjadi pada pelaksanaan sebuah kegiatan pemerintah, tinggal bagaimana untuk pengembangan kompetensi APIP itu sendiri.

Menurut Baker dan Sinkula (2005) kapabilitas merupakan kumpulan keterampilan yang lebih spesifik, prosedur, dan proses yang dapat memanfaatkan sumber daya keunggulan kompetitif. Pemaknaan kapabilitas tidak sebatas memiliki keterampilan (skill) saja namun lebih dari itu, yaitu lebih paham secara mendetail sehingga benar-benar menguasai kemampuannya dari titik kelemahan hingga cara mengatasinya. Kompetensi terletak pada bagian dalam setiap manusia dan selamanya ada pada kepribadian seseorang dan dapat memprediksikan tingkah laku dan performa secara luas pada semua situasi dan tugas pekerjaan (job tasks) (Spencer \& Spencer dalam Moeheriono, 2010). Berdasarkan pengertian tersebut di atas, dapat disimpulkan bahwa kompetensi adalah kemampuan 
dalam kerja dengan mengintegrasikan pengetahuan, keterampilan, kemampuan serta nilai-nilai pribadi berdasarkan pengalaman dan pembelajaran dalam rangka pelaksanaan tugasnya secara professional, efektif dan profesional. Berdasarkan hasil penelitian, kapabilitas APIP Kabupaten Kepulauan Talaud sudah sesuai dengan teori kapabilitas. APIP Kabupaten Kepulauan Talaud memiliki kemampuan dalam kerja dengan mengintegrasikan pengetahuan, keterampilan, kemampuan serta nilai-nilai pribadi secara profesional.

\section{Kendala yang Dihadapi APIP Daerah Kabupaten Kepulauan Talaud dalam Pelaksanaan Tugas dan Fungsinya. Kendala Sumber Daya Manusia}

Berdasarkan analisis hasil penelitian dengan menggunakan teknik triangulasi, dalam upaya meningkatkan kapabilitas APIP pada level II diketahui ada beberapa kendala yang dihadapi dalam pelaksanaan tugas dan fungsi APIP Kabupaten kepulauan Talaud yang dapat dikelompokkan kedalam dua tema yaitu kendala sumber daya manusia dan kendala sarana prasarana. Dalam upaya peningkatan kapabilitas APIP ke level yang lebih terpercaya lagi maka jumlah dan kualitas APIP itu sendiri harus dioptimalkan agar indikator pada level III kapabilitas APIP bisa tercapai. Namun saat ini jumlah sumber daya auditor Kabupaten Talaud masih kurang dan tidak sesuai dengan analisis beban kerja yang seharusnya 35-40 tenaga auditor. Ini berpengaruh pada manajemen waktu yang tidak akan cukup dengan jumlah auditi yang diperiksa sehingga berpengaruh pada target penyelesaian yang sudah ditentukan.

Sumber daya manusia sangat penting dalam menentukan kelangsungan kegiatan suatu organisasi. Sumber daya manusia yang berkualitas dengan jumlahnya yang banyak tentunya akan menentukan keberhasilan organisasi dalam menyusun rencana, melaksanakan kegiatan operasional dan mengendalikan jalannya organisasi untuk mencapai tujuan yang telah ditetapkan.

Menurut teori implementasi kebijakan publik oleh Edward III dalam Agustino (2016) Staf/SDM adalah sumber daya utama dalam implementasi kebijakan dalam staf. Kegagalan yang sering terjadi dalam implementasi kebijakan salah satunya disebabkan oleh karena staf yang tidak mencukupi, memadai, ataupun tidak kompeten dibidangnya. Penambahan jumlah staf dan implementor saja tidak cukup, tetapi diperlukan juga kecukupan staf dengan keahlian dan kemampuan yang diperlukan (kompeten dan kapabilitas) dalam mengimplementasikan kebijakan atau melaksanakan tugas yang diinginkan oleh kebijakan itu sendiri. Sumber daya yang paling penting bagi suatu organisasi adalah orang yang memberikan kerja, bakat, kreativitas, dan semangat kepada organisasi. Suatu implementasi akan berjalan dengan efektif, apabila implementor memiliki sumber daya yang memadai untuk melaksanakan kebijakan tersebut.

Berdasarkan hasil wawancara pada seluruh informan, maka dapat disimpulkan bahwa salah satu kendala yang dihadapi oleh APIP Kabupaten Talaud dalam upaya meningkatkan kapabilitas APIP ke level III yaitu kurang optimalnya pengelolaan sumber daya manusia dari segi kuantitas atau jumlah auditor yang tidak memadai dan kualitas yang masih harus terus dikembangkan terus menerus dimana pada standar APIP dalam Men-PAN nomor PER/05/M.PAN/03/2008 tentang Standar Audit Aparat Pengawasan Intern Pemerintah menyebutkan bahwa untuk kompetensi auditor harus terus dikembangkan artinya pengembangan kompetensi berkelanjutan.

Kesulitan sumber daya manusia merupakan sumber masalah dalam organisasi. Konsekuensi dari hal ini adalah tersedianya sumber daya manusia yang mempunyai kapasitas sebagai perencana dan pelaksana program kegiatan. Kapasitas ini ditentukan oleh kapabilitas, kompetensi dan produktivitas kerja. Kapabilitas sumber daya manusia yang berorientasi pada pengetahuan (knowledge) dan keterampilan (skill) yang akan menentukan berhasilnya seseorang menyelesaikan pekerjaan yang dibebankan kepadanya secara optimal. Tanpa sumber daya kebijakan hanya tinggal dikertas menjadi dokumen saja. Maka dari itu sumber daya APIP Kabupaten Talaud perlu ditambah lagi agar dapat meningkatkan kinerja dalam rangka memenuhi indikator untuk menuju ke level III kapabilitas APIP, lebih dari itu standar pelaksanaan audit APIP harus dilaksanakan dengan optimal untuk penjaminan mutu. Selanjutnya kualitas APIP harus terus dioptimalkan sesuai dengan standar pada Men-PAN bahwa pengembangan kompetensi auditor harus berkelanjutan agar pelaksanaan tugas pemeriksaan akan tepat sasaran dan sesuai target yang ditentukan dari tahun ke tahun. 


\section{Kendala Sarana Prasarana}

Saran prasarana berpengaruh terhadap kinerja APIP karena dalam pelaksanaan tugas dan

fungsi harus diimbangi juga dengan fasilitas-fasilitas penunjang. Keberadaan sarana prasarana (infrastruktur) yang memadai sangat penting dalam peningkatan kinerja sebuah organisasi dalam hal ini organisasi pemerintah yaitu APIP Kabupaten Kepulauan Talaud. Dalam mendukung pelaksanaan tugas fungsi APIP pemerintah daerah khususnya inspektorat terus berbenah diri dari segi sarana prasaran terus dilakukan pengadaan untuk menunjang kinerja APIP dengan harapan akan efektif sesuai dengan standar pelaksanaan. Saat ini sudah ada kendaraan roda dua untuk mobilisasi auditor saat turun lapangan untuk melaksanakan pemeriksaan, alat-alat pemeriksaan seperti laptop, scan table, hammer test. Namun sarana prasarana yang ada belum memadai atau belum merata dan belum semua dimiliki dan masih harus di optimalkan pengadaannya agar dalam pelaksanaan tugas pemeriksaan bisa terselesaikan sesuai dengan waktu yang sudah di targetkan. Saat ini APIP Talaud dalam pelaksanaan tugas fungsinya terkendala dengan kurang memadainya sarana prasaran yang berpengaruh pada manajemen waktu. Karena kurangnya fasilitas yang ada sehingga masih harus bergantian dalam menggunakan fasilitas-fasilitas yang seharusnya baik tiap IRBAN maupun auditor sudah harus memilikinya masing-masing.

Selain kendala kurangnya fasilitas/alat pemeriksaan dari hasil wawancara pada informan, kendala dalam pelaksanaan tugas ke tempat-tempat pemeriksaan yaitu kurangnya kendaraan seperti roda empat, sedangkan pada saat melakukan pemeriksaan ke desa-desa harus melalui perjalanan jauh dan melewati hutan-hutan dengan membawa alat pemeriksaan yang ada akan membuat ketidakamanan dalam berkendara, dan akan rentan kecelakaan. Namun pada situasi tertentu auditor harus menggunakan roda dua karena medan jalan yang hanya bisa dilalui oleh roda dua, dan saat ini roda dua masih kurang. Karena di Kabupaten Talaud sendiri selain jalur darat ada juga jalur laut yang harus dilewati untuk sampai ke desa atau OPD yang harus diperiksa

Menurut teori implementasi kebijakan publik oleh Edward III dalam Agustino (2016) Indikator sumber daya terdiri dari beberapa elemen dan salah satunya adalah fasilitas. Fasilitas fisik juga merupakan faktor penting dalam implementasi kebijakan. Implementor mungkin memiliki staf yang mencukupi, mengerti apa yang harus dilakukan dan memiliki wewenang untuk melaksanakan tugasnya, tetapi tanpa adanya fasilitas pendukung (sarana dan prasarana) maka implementasi kebijakan tersebut tidak akan berhasil. Selain pentingnya sumber daya auditor dalam melaksanakan kebijakan pemerintah yang mencanangkan peningkatan kapabilitas APIP level III pada RPJMN fasilitas atau sarana prasarana juga cukup penting dalam menunjang keberhasilan kebijakan pemerintah dan tujuan organisasi APIP. Walaupun sumber daya auditor Kabupaten Talaud sudah memadai tetapi tidak didukung dengan fasilitas penunjang dalam pelaksanaan tugas, maka itu semua akan sia-sia. Sumber daya dan fasilitas adalah dua indikator penentu keberhasilan pelaksanaan kebijakan pemerintah.

Walaupun APIP Talaud sudah mengalami peningkatan yang cukup signifikan namun itu belum mampu menempatkan kapabilitas APIP pada level III (integrated), saat ini masih terdapat kendala-kendala internal yang dihadapi APIP itu sendiri. Seperti yang sudah diketahui kapabilitas APIP Kabupaten Talaud saat ini belum berada pada level III, mengacu pada RPJNM 2014-2019 seluruh APIP Indonesia harus berada pada level III (integrated) pada tahun 2019. Untuk mengatasi kendala-kendala yang ada diperlukan upaya-upaya dan strategi, ketika upaya dan strategi dilakukan secara optimal maka akan menghasilkan kinerja yang baik dan secara langsung tingkat kapabilitas APIP akan mengalami peningkatan dan dipercaya.

\section{Upaya-upaya yang Dilakukan untuk Meningkatkan Kapabilitas APIP Daerah Kabupaten Kepulauan Talaud Menuju Level III. Upaya Mengatasi Kendala Sumber Daya Manusia}

Berdasarkan hasil wawancara dan analisis tentang upaya mengatasi sumber daya manusia, maka dapat disimpulkan yakni menambah atau merekrut auditor lagi agar dalam pelaksanaan tugas fungsi APIP bisa terlaksana sesuai dengan waktu yang telah ditargetkan artinya semua sesuai dengan analisis beban kerja. Selain itu untuk meningkatkan kemampuan auditor inspektorat selalu mengikutkan auditor dalam diklat-diklat teknis, seminar-seminar yang berkaitan dengan tugas fungsi auditor yang diadakan oleh BPKP, BPK dan mengadakan pelatihan kantor sendiri (PKS) agar kualitas 
APIP Kabupaten Talaud bisa lebih meningkat dari segi kualitas, dan ini merupakan strategi inspektorat Talaud dalam mengatasi masalah sumber daya.

Dimana dalam standar audit APIP Men-PAN 1020 - Kewajiban auditor untuk meningkatkan kemampuan. Auditor harus secara terus-menerus meningkatkan kemampuan teknik dan metodologi audit. Dengan memperbaiki teknik dan metodologi audit, auditor dapat meningkatkan kualitas audit dan mempunyai keahlian yang lebih baik untuk menilai ukuran kinerja atau pedoman kerja yang digunakan oleh auditi.

Tujuan pengembangan sumber daya manusia mempunyai dua dimensi, yaitu dimensi individual dan dimensi institusional. Tujuan yang berdimensi individual mengacu kepada sesuatu yang dicapai oleh seorang pegawai, sedangkan tujuan berdimensi institusional mengacu pada apa yang ingin dicapai oleh organisasi. Dengan pengembangan sumber daya manusia yang dalam hal ini pegawai maka akan dapat meningkatkan kemampuan pegawai baik kemampuan profesionalnya, kemampuan wawasannya, maupun kemampuan pengabdiannya sehingga dapat meningkatkan kinerja organisasi sehingga level III kapabilitas APIP bisa tercapai sebagaimana yang telah tertuang dalam RPJMN 2014-2019.

\section{Upaya Mengatasi Kendala Sarana Prasarana}

Dari hasil wawancara dan analisa tentang upaya dalam mengatasi kendala fasilitas, inspektorat Kabupaten Kepulauan Talaud juga telah melakukan pengadaan kembali sarana prasarana seperti kendaraan bermotor untuk mobilisasi dalam pemeriksaan serta pengadaan fasilitas dalam pemeriksaan sesuai dengan standar yang ada yaitu penambahan pengadaan hammer test, scan table, penambahan laptop dan print yang dibawa saat melakukan pemeriksaan, dan kamera. Inspektorat sedang mengupayakan pengadaan fasilitas-fasilitas yang masih kurang secara bertahap agar masalah kendala fasilitas bisa teratasi.

\section{Kesimpulan}

APIP Talaud saat ini masih berada pada level II dengan catatan. APIP daerah Kabupaten Kepulauan Talaud hingga saat ini terus melakukan pembenahan dan perbaikan. Saat ini auditor berjumlah 14 orang dan baru 12 orang yang sudah di lantik dan diberikan surat keterangan oleh bupati sendiri dan 2 orang yang telah mengikuti ujian untuk menjadi auditor tetapi masih menunggu untuk dilantik dan diberikan surat keterangan oleh bupati. Kendala yang dihadapi APIP daerah Kabupaten Kepulauan Talaud dalam pelaksanaan tugas dan fungsinya, yaitu sumber daya manusia dan sarana dan prasarana. Sehingga, berdasarkan kendala-kendala tersebut dapat dikemukakan upaya-upaya yaitu 1) upaya sumber daya manusia, Pemerintah daerah melalui inspektur Kabupaten Kepulauan Talaud sendiri dalam rangka peningkatan kapabilitas APIP pada level III telah menyekolahkan beberapa auditor selain terpenuhinya jumlah auditor sesuai dengan analisis beban kerja, juga dari segi kualitas seperti wawasan, profesionalisme serta pengalaman akan lebih memadai dan lebih dipercaya. Peran APIP yang efektif dipengaruhi juga oleh kualitas sumber daya APIP itu sendiri. 3) upaya sarana dan prasarana, upaya dan strategi yang dapat dilakukan adalah dengan melakukan penambahan serta pengadaan untuk sarana prasarana yang mendukung auditor dalam pemeriksaan baik dilapangan maupun di inspektorat sendiri.

\section{Saran}

Perlu adanya penambahan jumlah auditor sehingga kebutuhan akan auditor bisa terpenuhi dan proporsional dengan jumlah auditi yang ada, sehingga sesuai dengan analisis beban kerja. Pemerintah daerah juga harus mengeluarkan kebijakan yaitu mengikutsertakan pegawai yang ada di inspektorat untuk mengikuti tes auditor atau melalui inpassing agar kebutuhan akan auditor bisa terpenuhi sesuai standar pelaksanaan APIP. Kemudian inspektorat harus selalu mengikutkan setiap diklat-diklat teknis yang diadakan oleh BPKP secara merata keseluruh auditor, ini dimaksudkan agar semua kualitas auditor bisa meningkat secara merata dan kompetensi yang sudah ada akan semakin maju dan berkembang. Sehingga dalam pelaksanaan tugas fungsi akan terlaksana dengan efektif. Dalam menunjang pelaksanaan tugas APIP sarana prasarana harus ditambah dan dilengkapi sesuai dengan standar yang ada. Seperti pengadaan alat uji mutu beton hammer test, scan table, laptop, print, dan kamera. Ini diharapkan bisa dimiliki setiap auditor agar bisa menghasilkan kinerja yang tepat guna, 
akuntabel dan sesuai dengan target waktu. Selain itu pengadaan sarana mobilisasi saat akan melakukan pemeriksaan agar tidak terkendala dengan letak geografis dan cuaca yang ada.

\section{Daftar Pustaka}

Agustino, L. 2016. Dasar-dasar kebijakan publik (Edisi Revisi). Alfabeta.Bandung.

Badan Pemeriksaan Keuangan RI, bpk.go.id , Ikhtisar Hasil Pemeriksaan (2018). Badan Pemeriksaan Keuangan RI. , Beranda Badan Pemeriksaan Keuangan RI. , Berita Badan Pemeriksaan Keuangan RI.

Baker, W. E., \& Sinkula, J. M. 2005. Market orientation and the new product paradox. Journal of Product Innovation Management, 22(6), 483-502.

BPKP Republik Indonesia. 2017. Perwakilan Sulawesi Utara. LKPD Kabupaten Kepulauan Talaud.

Gamayuni, R R. 2016. Efektivitas Fungsi Audit Internal: Faktor Yang Mempengaruhi, Dan Implikasinya Terhadap Kualitas Pelaporan Keuangan (Survei Pada Inspektorat Pemerintah Provinsi/Kota/Kabupaten Di Pulau Jawa).

Marlaini, M., Aliamin, A., \& Indriani, M. 2018. Evaluasi Efektivitas Penguatan Peran Aparat Pengawasan Intern Pemerintah Dalam Paradigma Baru (Studi Kasus Pada Salah Satu Inspektorat Di Aceh). Jurnal Perspektif Ekonomi Darussalam, 4(1), 95-108.

Matei, A. M., Karamoy, H., \& Lambey, L. 2017. Optimalisasi Fungsi Inspektorat dalam Pengawasan Keuangan Daerah di Kabupaten Kepulauan Talaud. Jurnal Riset Akuntansi Dan Auditing" Goodwill", 8(1).

Moeheriono. 2010. Pengukuran Kinerja Berbasis Kompetensi. Surabaya: Ghalia Indonesia.

Peraturan Pemerintah No. 60 Tahun 2008 Tentang Sistem Pengendalian Intern Pemerintah. , Pasal 2 Peraturan Pemerintah No. 60 Tahun 2008 Tentang Sistem Pengendalian Intern Pemerintah.

Peraturan Presiden Nomor 2 Tahun 2015 Tentang Rencana Pembangunan Jangka Menengah Nasional Tahun 2015 - 2019.

Peraturan Kepala Badan Pengawasan Keuangan dan Pembangunan Nomor XXX Tahun 2015 Tentang Pedoman Teknis Peningkatan Kapabilitas Aparat Pengawasan Intern Pemerintah Secara Mandiri (Self Improvement).

Peraturan Menteri Negara Pemberdayaan Aparatur Negara No. Per/05/M.Pan/03/2008

Tentang Standar Audit Aparat Pengawasan Intern Pemerintah. Standar 2200 Mengenai Keahlian. Standar 2210 Mengenai Latar belakang Pendidikan Auditor. 1020 Mengenai Pendidikan Berkelanjutan.

Sugiyono. 2016. Memahami Penelitian Kualitatif. Alfabeta, Bandung.

Supragita, I. 2017. Evaluasi Efektivitas Aparat Pengawasan Intern Pemerintah (APIP) Kabupaten Bengkulu Utara (Doctoral Dissertation, Universitas Gadjah Mada). 